\title{
The Monogenean Parasite Fauna of Cichlids: A Potential Tool for Host Biogeography
}

\author{
Antoine Pariselle, ${ }^{1}$ Walter A. Boeger, ${ }^{2}$ Jos Snoeks, ${ }^{3,4}$ Charles F. Bilong Bilong, ${ }^{5}$ \\ Serge Morand, ${ }^{1}$ and Maarten P. M. Vanhove ${ }^{3,4}$ \\ ${ }^{1}$ ISE-M, UMR5554 CNRS, UR226 IRD (ex-ORSTOM), Université Montpellier II-CC 063, 34095 Montpellier Cedex 5, France \\ ${ }^{2}$ Laboratório de Ecologia Molecular e Parasitologia Evolutiva, Grupo Integrado de Aquicultura e Estudos Ambientais, \\ Universidade Federal do Paraná, Setor de Ciências Biológicas, Departamento de Zoologia, Caixa Postal 19073, CEP 81531-980, \\ Curitiba, PR, Brazil \\ ${ }^{3}$ Ichthyology Unit, African Zoology Department, Royal Museum for Central Africa, Leuvensesteenweg 13, 3080 Tervuren, Belgium \\ ${ }^{4}$ Laboratory of Animal Diversity and Systematics, Biology Department, Katholieke Universiteit Leuven, Charles Deberiotstraat 32, \\ 3000 Leuven, Belgium \\ ${ }^{5}$ Laboratoire de Parasitologie et d'Ecologie, Département de Biologie et Physiologie Animales, Université de Yaoundé I, BP 812, \\ Yaoundé, Cameroon
}

Correspondence should be addressed to Maarten P. M. Vanhove, maarten.vanhove@bio.kuleuven.be

Received 15 December 2010; Revised 21 February 2011; Accepted 19 April 2011

Academic Editor: Stephan Koblmüller

Copyright (C) 2011 Antoine Pariselle et al. This is an open access article distributed under the Creative Commons Attribution License, which permits unrestricted use, distribution, and reproduction in any medium, provided the original work is properly cited.

We discuss geographical distribution and phylogeny of Dactylogyridea (Monogenea) parasitizing Cichlidae to elucidate their hosts' history. Although mesoparasitic Monogenea (Enterogyrus spp.) show typical vicariant distribution, ectoparasitic representatives from different continents are not considered sister taxa, hence their distribution cannot result from vicariance alone. Because of the close host-parasite relationship, this might indicate that present-day cichlid distribution may also reflect dispersal through coastal or brackish waters. Loss of ectoparasites during transoceanic migration, followed by lateral transfer from other fish families might explain extant host-parasite associations. Because of its mesoparasitic nature, hence not subject to salinity variations of the host's environment, Enterogyrus could have survived marine migrations, intolerable for ectoparasites. Host-switches and salinity transitions may be invoked to explain the pattern revealed by a preliminary morphological phylogeny of monogenean genera from Cichlidae and other selected Monogenea genera, rendering the parasite distribution explicable under both vicariance and dispersal. Testable hypotheses are put forward in this parasitological approach to cichlid biogeography. Along with more comprehensive indepth morphological phylogeny, comparison with molecular data, clarifying dactylogyridean evolution on different continents and from various fish families, and providing temporal information on host-parasite history, are needed to discriminate between the possible scenarios.

\section{Introduction: Explanations to the Current Distribution Pattern of Freshwater Fish Groups}

Organisms with limited dispersal abilities are generally considered to be useful tools in historical biogeography. Examples include amphibians [1] and freshwater fishes [2,3]. At the heart of many discussions on the evolutionary history and distribution patterns of major freshwater fish groups is the vicariance versus dispersal debate (e.g., $[4,5])$. Although vicariance-based scenarios have classically been favoured, de Queiroz [6] gives an overview of how the importance of (often seemingly unlikely) dispersal events has been underestimated in historical biogeography, though his examples stem mostly from plants and terrestrial biota.

It is generally accepted that the distribution of several ancient freshwater groups such as Dipnoi (lungfishes) and Osteoglossiformes (bony tongues) results from major vicariant events after the breakup of Gondwana [7]. However, because of conflicting evidence, the discussion continues for 
more recent groups. Hertwig [8] discussed the biogeographic implications of the phylogeny of the Cyprinodontiformes (rivulines, killifishes, and live bearers). He explained their distribution by vicariance events in the basal clades, combined with subsequent dispersal, and stressed the discrepancy of the vicariance hypothesis with the paleontological record. For example, in aplocheiloid killifishes, the fossil record is much younger than the supposedly African-South American drift-vicariance event [9].

The same is true within the Characiformes (characins), for example, in Alestidae; Zanata and Vari [10] forwarded a clear vicariance hypothesis to explain their distribution and relationships. In addition, they mention typically vicariant biogeographic patterns in two other groups of Characiformes with African-South American sistergroup relationships. However, Calcagnotto et al. [11], in a molecular analysis, mostly confirming earlier morphology-based trees, concluded that marine dispersal cannot be excluded a priori and that a simple model of vicariance could not explain the biogeographic history of the order.

Within the Siluriformes (catfishes), the situation is more complex since several taxa are marine inhabitants. Sullivan et al. [12] could not confirm the existence of a supposedly trans-Atlantic clade suggested by others, but conversely, their overall tree of Siluriformes did not contradict a general vicariant distribution pattern of tropical freshwater catfishes either. A few recent publications have offered new angles to the vicariance versus dispersal debate. To explain the unexpected discovery of a Mesoamerican catfish within an African clade, Lundberg et al. [13] postulated a northern ancient intercontinental passage in warmer periods, including dispersal through freshened warm surface waters of the Arctic and adjacent oceans. Such episodic fresh surface waters have been suggested by Brinkhuis et al. [14] as an explanation for the presence of the freshwater fern Azolla and freshwater microfossils in Eocene marine deposits.

\section{The Case of Cichlidae}

For Cichlidae, the discussion is far from over either, as they exhibit a comparable biogeographic pattern found in Cyprinodontiformes, with basal lineages occurring in India and Madagascar, and the common problem of discordance between their fossil record and their age under the vicariance hypothesis [8]. Most recent arguments, however, seem to favour the vicariance model (e.g., [15-17]), but the dispersal model could not be eliminated. In fact, the numerous studies that have examined the fossil record and morphological and/or molecular phylogenies of the world's cichlid fauna (e.g., $[9,15,17-29])$ have not been able to end all doubts on the choice between the two main hypotheses explaining their current distribution pattern.

The first hypothesis postulates that the cichlid fishes originated ca. 130 million years ago (MYA) in Gondwana. Their current disjunctive distribution area (Africa, including Madagascar; South and Central America, Texas and the Caribbean; southern mainland India and Sri Lanka; the Levant and Iran [30]) comprises mostly Gondwanan regions; hence cichlids would have already been present in the major part of their current range before the splitting up of this super-continent. As for their non-Gondwanan occurrence in Texas, the Caribbean, the Levant, and Iran, migration through river systems over more recent landbridges is assumed (e.g., [16]) though the dispersal mode is still debated for Central America and the Caribbean $[31,32]$. This implies that cichlid evolutionary history and present large-scale distribution on the continents resulted from major vicariant events and that cichlids did not need to cross extensive marine barriers to reach these distribution areas.

The second hypothesis, in line with the fossil data, suggests that cichlid fishes originated near Madagascar, or more precisely, that the cichlids living there belong to ancestral lineages, in view of their paraphyly $([25,33,34]$ and references therein). Consequently, cichlids would have secondarily colonized their current disjunctive distribution areas [24-26]. This scenario assumes that cichlid evolutionary history and present distribution have resulted from dispersal across various marine water channels.

According to Chakrabarty [15], the only way to resolve the controversy of the origin of Cichlidae (except for the discovery of a cichlid fossil older than $65 \mathrm{MY}$ ) is to falsify either of the two hypotheses. As the dispersal hypothesis is untestable because any distribution pattern can be explained by dispersal, Chakrabarty [15] suggested four potential means to show the vicariance hypothesis incorrect. Three of these falsifiers are based on the demonstration of an incompatibility between the timing of two supposedly concomitant events (one linked to the divergence of lineages, the other to geological processes); the fourth one includes the discovery of the same cichlid species on both sides of a supposed barrier to dispersal.

One of the potential "timing" falsifiers involves the use of molecular clock estimations, the absolute accuracy of which still remains unknown (e.g., [35] versus [36, 37]). However, Azuma et al. [17] made a strong case in calculating divergence times of major cichlid lineages, based on molecular evolutionary rates of large mitogenomic datasets of six cichlid species, leading to additional support for the vicariance hypothesis. As for the discovery of a new cichlid species on both sides of a marine channel, the likelihood is very low. The same applies to the finding of a cretaceous cichlid fossil. In comparison with other freshwater fishes spanning such a period of time, this would indeed imply a relatively large gap in the fossil record [25]. Furthermore, the advanced position of perciformes in teleost phylogeny (several higher level taxa encompassing the cichlids do not appear before the Gondwanan breakup) and the extensive fossil record available of several cichlid lineages make such a discovery improbable [38].

\section{Parasites as an Additional Source of Information}

Another solution might come from the use of a separate and independent data set related to cichlids. It is well established that parasites can furnish information on their hosts' ecology 
and (past and current) distribution [39-42]. Following Hoberg [43] and Nieberding and Olivieri [42], we could use parasites as keystones in biogeography, or proxies, to provide a new dimension to understand ecological interactions, distribution patterns, and the history of geographic regions and biota.

Some work has been done in this framework to infer host biogeography [44-55]. More specifically, interesting examples include the reconstruction of biogeographical events through the analysis of parasite communities [56-59] and the detection of patterns at a higher resolution than host genetics would permit [60-62]. Parasite phylogenetic data can also yield supporting or complementary information on host phylogenies [63-67]. Surprisingly, few studies refer to fishes and their associated monogenean parasites whereas these organisms seem useful as indicators of host biogeography and phylogeny. Indeed, they are strictly parasitic (i.e., adults cannot survive for a long time as free-living organisms), holoxenous (i.e., they have a direct lifecycle, with a short free-living larval stage which actively infests a new host), and generally oioxenous (i.e., parasite species are often species specific with regard to their host). A limited number of cases were made using these parasites, applying them in the fields of genetic population substructuring [68], historical patterns of their hosts' dispersal [69] or distribution [70], (co-)phylogenetic patterns [71-73], and host identification [74].

Pariselle et al. [75] used data from West African cichlids and concluded that monogenean species can behave similarly to the alleles of genes of their fish hosts. Distribution, and therefore biogeography, of the hosts will directly affect that of their monogeneans. Conversely, information provided by these parasites should be very useful for studies in fish biogeography. Importantly, as demonstrated by PérezPonce de Léon and Choudhury [59] for South and Central American cichlids, a phylogenetic study of both host and parasite taxa is paramount to infer hypotheses on historical biogeography. Evidently, a geographically restricted availability of parasite records can seriously hamper an analysis. For example, theories on the "original" host, needed to infer host-switching or dispersal pathways, are hard to infer when certain regions or host taxa are undersampled. In addition, insufficient sampling ensues obvious problems related to how "real" absence data are when considering community composition [58].

Here we illustrate how parasite information may complement the discussion on vicariance versus dispersal hypotheses for cichlid age and distribution processes.

\section{The Monogenean Parasite Fauna of Cichlids}

4.1. Data Collection on Cichlid Parasites. Because of the oioxenous host specificity of many monogenean species, the (geological) time scale and the biogeographical distribution of their hosts (no genus is represented naturally on two different continents) [76, 77], the approach used within the framework of this study is based on the generic rather than the species level. Some ancyrocephalid monogeneans from South American and African cichlids are known to exhibit a relatively low host specificity, infesting several host species [78, 79]. However, their otherwise often narrow species specificity would, in our view, render examining the parasite data at species level equivalent to the use of autapomorphic characters (instead of synapomorphic ones) in a phylogenetic tree, which is not appropriate [73] to infer the biogeographical history of the host. Furthermore, there are considerable differences in the number of parasite species reported from the various host genera. In view of the relatively low proportion of cichlid species worldwide examined for the presence of Monogenea, this imbalance is more likely to reflect differential sampling effort than variations in species richness between genera. Conversely, on the genus level, we feel confident the current state-of-theart approaches the actual parasite diversity on cichlids to a higher extent.

To the best of our knowledge, Figure 1 provides a complete overview of the 13 monogenean genera infecting cichlids. Unfortunately, a considerable proportion of available data is fragmentary and based on studies on a limited number of regions or host species. The most exhaustively studied assemblage is probably Ancyrocephalidae from West African tilapias. The exemplary nature of monogenean records worldwide is demonstrated by the fact that, while there are revisions and phylogenies available for certain well-defined taxa (e.g., Diplectanidae [80], Capsalidae [81]), comprehensive worldwide information on Monogenea of an entire fish family is extremely rare.

The worldwide distribution of monogenean genera described from cichlid hosts shows a clear difference between the distributions of ecto- (i.e., living on the host, directly in contact with the environment) and mesoparasite (i.e., living in a host body cavity and not in direct contact with the external environment [91]) genera. The mesoparasite Enterogyrus is present in Asia, the whole of Africa, and the Levant. Pariselle and Euzet [78] hypothesize that the Asian and African-Levantine representatives of this genus might be considered as belonging to separate genera, on the basis of the possession of two versus one haptoral transversal bar. However, the overall similarities in haptor and even male copulatory organ structure suggest the various Enterogyrus spp. to be very closely related anyway.

In contrast, all ectoparasitic genera are endemic to the continent where they occur. Two genera currently seem to display a more restricted distribution: Onchobdella and Urogyrus. The first one was expected, like other African ectoparasitic genera, to be present on the entire continent, and not only in West Africa, but was found to be specific to hosts whose distribution is limited to this region (Hemichromis Peters, 1858 and Pelmatochromis Steindachner, 1894). Urogyrus, being a mesoparasite like Enterogyrus, could potentially be present on several continents, but is only found on hosts whose distribution is restricted to Africa (including haplochromines from the East African Great Lakes [92]).

While the above-mentioned cichlid parasites are mostly dactylogyridean Monogenea, the nominal (albeit probably paraphyletic [93]) genus Gyrodactylus is a member of the Gyrodactylidae, first proposed by Van Beneden and Hesse 


\begin{tabular}{|c|c|c|c|c|c|c|}
\hline & Madagascar Asia & $\begin{array}{c}\text { West } \\
\text { Africa }\end{array}$ & $\begin{array}{c}\text { East } \\
\text { Africa }\end{array}$ & Levant & Iran & $\begin{array}{c}\text { South } \\
\text { America }\end{array}$ \\
\hline \multicolumn{7}{|l|}{ Ectoparasite genera } \\
\hline \multicolumn{7}{|l|}{ Insulacleidus Rakotofiringa and Euzet, 1983} \\
\hline \multicolumn{7}{|l|}{ Ceylonotrema Gussev, 1963} \\
\hline \multicolumn{7}{|l|}{ Sclerocleidoides Agarwal, Yadav, and Kritsky, 2001} \\
\hline \multicolumn{7}{|l|}{ Cichlidogyrus Paperna, 1960} \\
\hline \multicolumn{7}{|l|}{ Onchobdella Paperna, 1968} \\
\hline \multicolumn{7}{|l|}{ Scutogyrus Pariselle and Euzet, 1995} \\
\hline \multicolumn{7}{|l|}{ Gussevia Kohn and Paperna, 1964} \\
\hline \multicolumn{7}{|l|}{ Sciadicleithrum Kritsky, Thatcher, and Boeger, 1989} \\
\hline \multicolumn{7}{|l|}{ Trinidactylus Hanek, Molnar, and Fernando, 1974} \\
\hline \multicolumn{7}{|c|}{ Tucuranella Mendoza-Franco, Scholtz, and Rozkošná, 2010} \\
\hline \multicolumn{7}{|l|}{ Gyrodactylus von Nordmann, 1832} \\
\hline \multicolumn{7}{|l|}{ Mesoparasite genera } \\
\hline \multicolumn{7}{|l|}{ Enterogyrus Paperna, 1963} \\
\hline Urogyrus Bilong Bilong, Birgi, and Euzet, 1994 & & & & & & \\
\hline
\end{tabular}

FIGURE 1: Current state of knowledge on biogeographical distribution of monogenean genera from cichlid fishes (fields shaded in grey indicate presence), compiled on the basis of [78, 82-90] and additional unpublished data from the authors. Note that sufficient data are clearly lacking for some regions, for example, on whether or not Malagasy and South American cichlids host mesoparasitic Monogenea. Recent synonymisations are taken into account, as are nomina inquirenda, for instance Oreochromogyrus Ferdousi and Chandra, 2002, which most likely concerns misidentified Cichlidogyrus larvae [78]. Only records from hosts occurring under natural conditions on the respective continents are included.

[94]. Moreover, despite its extensive morphological plasticity (cfr. infra), Gyrodactylus species are rather conservative on the scale of the characters used in this study. Given the limited number of representatives known from cichlids, this genus would not yield a high resolution in a morphological phylogeny. As we need a cladistic analysis of the genera under study, Gyrodactylus will not be included in our investigation. In contrast, it should be noted that Gyrodactylus in itself could be a useful biogeographic tool [95], as can other gyrodactylids [70]. However, the limited molecular data available on African and South American Gyrodactylus species do not show any close affinities between them either [82].

4.2. Phylogenetic Analysis. A preliminary phylogenetic analysis was performed using selected morphological characters available in the literature. Genera included are all those known to parasitize cichlids and selected parasites from marine and freshwater perciform fishes (Table 1) from the different continents home to cichlids. Quadriacanthus, infesting siluriformes, was added as its representatives depict similar and comparable morphological features (e.g., hook morphology). The inclusion of these taxa allowed a preliminary test of the monophyly of the parasites of Cichlidae, which would be the expected pattern under cospeciation (either by vicariance or dispersal). The addition of genera from other fish groups provided a preliminary test that the parasitic fauna of cichlids could encompass sister lineages to parasites of other sympatric fish species, especially if the hypothesis of parasite loss during dispersal in marine waters was supported.

The hypothesis on their relationship was proposed based on parsimony analysis of 17 unordered homologous series (Appendix). The chosen putative homologous series are
TABle 1: Genera from non-cichlid hosts included in the phylogenetic analysis, with their host range.

\begin{tabular}{|c|c|c|}
\hline Genus & Host fish families & Reference \\
\hline $\begin{array}{l}\text { Diplectanum Diesing, } \\
1858\end{array}$ & $\begin{array}{l}\text { Muraenesocidae, Gerreidae, } \\
\text { Kuhliidae, Latidae, Lutjanidae, } \\
\text { Moronidae, Percichthyidae, } \\
\text { Polynemidae, Priacanthidae, } \\
\text { Sciaenidae, Serranidae, } \\
\text { Sillaginidae, Sphyraenidae, } \\
\text { Synancejidae, Terapontidae, } \\
\text { Toxotidae, Cynoglossidae, } \\
\text { Bagridae }\end{array}$ & {$[96]$} \\
\hline $\begin{array}{l}\text { Mastacembelocleidus } \\
\text { Kritsky, Pandey, } \\
\text { Agrawal, and Abdullah, } \\
2004\end{array}$ & Mastacembelidae & {$[97]$} \\
\hline $\begin{array}{l}\text { Euryhaliotrema Kritsky } \\
\text { and Boeger, } 2002\end{array}$ & $\begin{array}{l}\text { Sciaenidae, Haemulidae, } \\
\text { Sparidae, Lutjanidae }\end{array}$ & {$[69]$} \\
\hline $\begin{array}{l}\text { Chandacleidus Agrawal, } \\
\text { Tripathi, and Devak, } \\
2006\end{array}$ & Freshwater Ambassidae & {$[98]$} \\
\hline $\begin{array}{l}\text { Duplaccessorius Viozzi } \\
\text { and Brugni, } 2004\end{array}$ & Freshwater Percichthyidae & {$[99]$} \\
\hline $\begin{array}{l}\text { Protogyrodactylus } \\
\text { Johnston and Tiegs, } \\
1922\end{array}$ & $\begin{array}{l}\text { Marine Terapontidae; Marine } \\
\text { and brackish water Gerreidae }\end{array}$ & {$[100,101]$} \\
\hline $\begin{array}{l}\text { Quadriacanthus } \\
\text { Paperna, } 1961\end{array}$ & Clariidae and Bagridae & {$[102]$} \\
\hline
\end{tabular}

those considered less prone to errors introduced by incomplete or questionable interpretations of morphology in the original descriptions of the species. Five of the homologous series used pertain to the copulatory complex; all others, 
to the haptoral elements. Although both haptoral and copulatory complex, next to soft body parts, are important in Monogenea systematics [103], many other scientists focus their analyses solely on the attachment organ (e.g., [104106]). Its complexity and variability, as well as the higher number of comparable elements, make it easier to extract coded characters from the haptor than from the genitals. Moreover, several studies comparing morphological and molecular data in Ancyrocephalidae suggest that the attachment organ structure mirrors phylogenetic relationships on the level between genera or major lineages while the copulatory organ is more suitable for distinguishing closely related species $[107,108]$. The phylogenetic hypothesis was constructed in PAUP* v.4.0 b10 [109], with the Bremer support index [110-112] calculated with the help of TreeRot v.3.0 [113]. Initial analyses, using heuristic search (under a treebisection and reconnection branch swapping algorithm with 1000 random-addition-sequence replicates) provided individual consistency indices for character states used in successive weighting procedures [114] until values of the overall consistency (CI: [115]) and retention indices (RI: [116]) stabilized.

A total of 21 equally parsimonious trees (EPT) resulted from the analysis of parsimony (length $=13.97 ; \mathrm{CI}=0.81$; $\mathrm{CI}$ excluding uninformative characters $=0.76$; $\mathrm{RI}=0.85$ ) . The strict consensus cladogram, summarising the most parsimonious phylogenetic relationships recovered from all EPT between the analysed genera is presented in Figure 2. The genera with species limited to Cichlidae (shaded genera names on Figure 2) are represented by up to three independent groups. The phylogenetic hypothesis does not support a single monophyletic assemblage of parasites of Cichlidae.

\section{Information to Be Drawn from Cichlid Monogeneans}

Our review shows that dactylogyridean ecto- and mesoparasites of cichlid hosts differ in their distributions. This raises the question as to which of the above-mentioned hypotheses on the biogeographic pattern of cichlids best explains this distributional incongruence. We would expect similar patterns in their geographic distribution, assuming that all lineages, meso- and ectoparasitic, have an equally long association with their cichlid hosts, a similar evolutionary rate, and have equally been subjected to the same biogeographical and coevolutionary processes/events. The African ectoparasitic Cichlidogyrus (as well as the mesoparasitic Enterogyrus) was found to infect South American cichlids following introduction of their African hosts, and the American Sciadicleithrum was reported from African cichlids under artificial conditions [117]. This supports the view that the evolutionary divergence between African and Neotropical cichlids is not the reason they do not share ectoparasites.

Thus, it is likely that the source of discrepancies between the distribution patterns observed for meso- and ectoparasite $s$ resides in the fact that environmental factors may influence these parasite communities differently (e.g., [118]). In the framework of the dispersal hypothesis (see [25]), there is a single such factor that may influence the two types of parasites in two different ways. This theory assumes that there were successive migrations, taking place in different environmental conditions. Some hosts are assumed to have crossed marine waters (between Madagascar and Asia; Madagascar and Africa; West Africa and South America; Figure 3, black arrows) while others only used freshwater dispersal pathways (dispersal within Africa or South America; Figure 3, white arrows). Ectoparasites are directly affected by changes in the environment while mesoparasites such as Enterogyrus found in the stomach are not. Does this differential exposure to saline water allow us to favour one of both hypotheses on cichlid history? A couple of issues need to be addressed before this question can be answered.

5.1. Salinity Tolerance of Cichlidae and Monogenea. Many cichlids exhibit tolerance to a broad salinity range and some even display a mostly brackish lifestyle, such as representatives of the Asian Etroplus Cuvier, 1830, the only Iranian endemic cichlid Iranocichla hormuzensis Coad, 1982, and some African, Malagasy, and Neotropical species ([25] and references therein, [30, 32, 119-129]). Murray [25] and Briggs [9] used this ability as an important argument in favour of the recent dispersal hypothesis, but Sparks and Smith [16] contradicted the long-time survival of any cichlid species in saltwater conditions. Although, at least under natural conditions, there are no fully marine cichlid species at present, several wild populations occur in (highly) saline environments (e.g., Sarotherodon melanotheron Rüppell, 1852 in the Gambia and Senegal rivers [130], in Hann bay (off Dakar), Senegal and in Saint Jean bay, Mauritania; Tilapia guineensis (Günther, 1862) in Hann bay (off Dakar), Senegal (A. Pariselle, pers. obs.)).

Cichlids were possibly able to survive in marine environments, but this may not have been the case for their monogenean parasites, whose tolerance to salinity variations is generally shown to be low. Indeed, osmotic shocks are commonly used as a treatment against ectoparasitic Monogenea [123, 131-134]. Pariselle and Diamanka [135] showed that $S$. melanotheron lost all monogenean gill parasites with the increase of water salinity $(>35 \mathrm{~g} / \mathrm{L})$, both in a natural environment and under experimental conditions.

On the other hand, Enterogyrus has been reported from highly saline waters [83]. The biogeography of mesoparasites (Enterogyrus) seems to display a vicariant history, as the same genus is present in Asia and Africa (Figure 1). The lack of shared ectoparasites between continents and the most often limited (as compared to their hosts') salinity tolerance of Cichlidogyrus is mentioned by Paperna [83] as an argument for the marine dispersal theory. Indeed, one could hypothesize that marine dispersal events in cichlids caused them to lose their ectoparasites, while retaining their mesoparasites, unexposed to the saline water. This could explain the incongruence between the distribution patterns of ecto- and mesoparasitic Dactylogyridea. However, for this conclusion to be drawn, it is necessary to know the interrelationships between the various monogenean genera under study. 


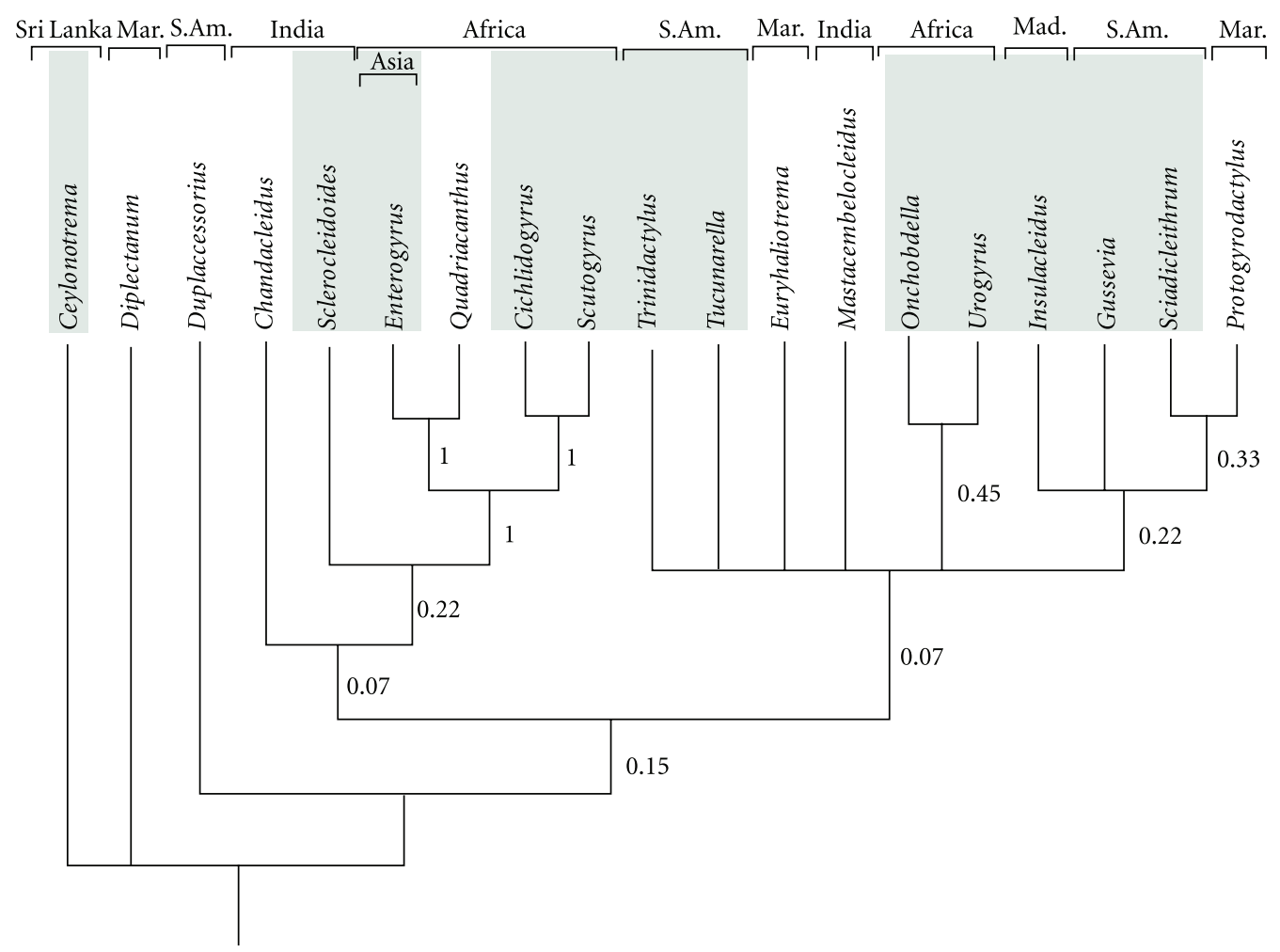

FIGURE 2: Strict consensus cladogram (of 21 EPT) depicting the putative phylogenetic relationship of Monogenea from Cichlidae (shaded rectangles) and other host groups. As branch support, Bremer support values are shown. Geographic distribution of species of each genus is depicted above generic names (“Mar.”: marine; “Mad.”: Madagascar; “S. Am.”: South America).

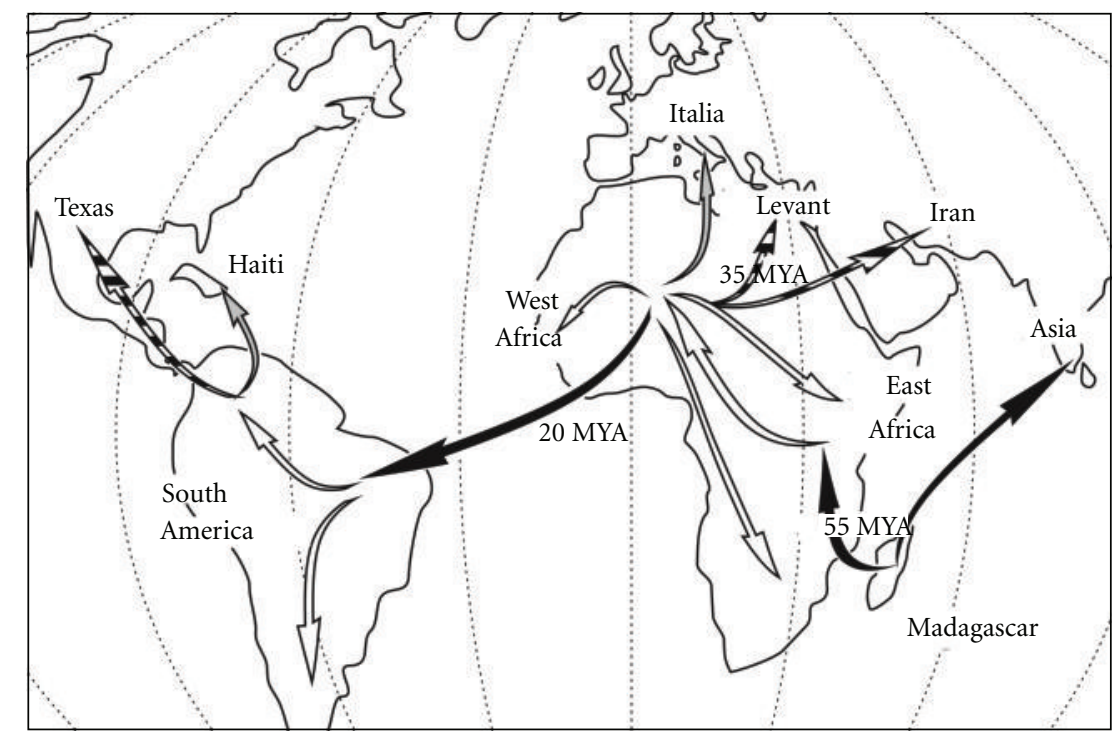

Figure 3: Simplification of Murray's hypothesis [25] on the origin and biogeography of the world's cichlids. Arrows symbolising dispersal routes are indicated as follows: marine (black); freshwater (white); unresolved (black and white); unknown (fossils only; grey).

5.2. Lessons from the Cladistic Analysis. The morphology of Monogenea and other flatworms is prone to display homoplasy, suggesting molecular phylogenetics to be needed to conclusively resolve their evolutionary relationships $[81,136$, 137]. Indeed, plasticity has been shown both in haptoral [138-142] and genital [143-145] structures. This demon- strates that not only phylogeny but also geography, hostrelated and environmental factors, and (sexual) selection may influence the morphology of monogenean hard parts. On the other hand, most of this variability is continuous/quantitative and between conspecific individuals, and, hence, should not represent a significant interference in 
construction of phylogenetic hypotheses based on discrete characters differing between genera. Moreover, ambiguities or resolution problems related to morphological phylogenies were mostly shown in groups of organisms displaying taxonomic difficulties and a limited number of discretely varying haptoral characters (e.g., gyrodactylid Monogenea [137]), lacking sufficient characters comparable throughout the family (e.g., six in capsalid Monogenea [81]), or where plastic characters, prone to loss or acquisition, were used (e.g., mouthpart structure reflecting trophic adaptation in lysianassoid Amphipoda [146]). In contrast, based on a limited number of species of ancyrocephalid Dactylogyridea, there are clear indications that haptor morphology contains phylogenetic signal $[107,108]$. On the level within or between genera, haptoral (and, on the between-species level: genital) structure does not conflict with molecular taxon boundaries and is systematically informative. Indeed, on these levels, geography or host characteristics do not seem to influence haptor morphology in this monogenean family.

The only genetic data on monogeneans infecting cichlid fishes stem from African species [100, 107], and are therefore uninformative for intercontinental comparison. Hence, a morphological phylogenetic hypothesis, based on a combination of haptoral and genital elements, seems a reasonable approach given the currently available knowledge. As any scientific hypothesis, it is prone to extensive reconsideration once sufficient genetic data are collected, as such data will yield a higher number of informative characters [147] compared to the presently available morphological knowledge. The morphological phylogenetic hypothesis (Figure 2) is fundamentally compatible with the results of the molecular phylogeny proposed by Mendlová et al. [100], with some more conspicuous coincidences (e.g., on the sistergroup relation of Scutogyrus and Cichlidogyrus). Also the close affinity between Ceylonotrema and Diplectanum might merit further scrutiny, as the ventral and dorsal bars of Ceylonotrema indeed show similarities to those in diplectanids. As molecular phylogenetics also faces, among others, problems with homoplasy [148-151], combining insights from both phenotypic and genetic classification in testing hypotheses and identifying uncertainties seems the most fruitful way forward (e.g., Rota-Stabelli et al. [152] for deep phylogeny of arthropods).

Although the above-mentioned flaws limit the interpretation we can give to our tree reconstruction in Figure 2, which should not be regarded as a definitive hypothesis on dactylogyridean evolutionary history, this tree provides the first comprehensive interpretation on phylogenetic relationships among cichlid monogeneans. Although based on morphological characters, it represents a phylogenetic hypothesis that may be tested based on molecular data. Furthermore, the CIs and RI of the tree demonstrate the existence of phylogenetic signal, independent of the number of homologous series available.

The cladogram indicates that parasitizing on cichlids is a polyphyletic character in Dactylogyridea. The non-sistergroup relationship of the ectoparasitic Dactylogyridea of cichlids on the different continents seems an interesting argument to support the dispersal hypothesis. On the other hand, if the parasites distribution is to be explained mainly by oceanic dispersal (of their hosts), one would expect their phylogenetic relationships to follow continental borders (as suggested for Gyrodactylidae by Boeger et al. [95]). The ectoparasite genera of different continents, however, are not each other's sister taxa based on the morphological cladogram (Figure 2). Hence, host-switching events from other fish groups are required, under whatever scenario, to explain the host-parasite distribution observed in the preliminary cladogram. Therefore, the evolutionary history of other fish families serving as "source hosts" should be considered.

Because Monogenea with a marine lifestyle appear as sister taxa to several cichlid (and thus, freshwater) parasites in our cladogram, lateral transfer from other (including marine, necessitating freshwater/marine transition) hosts could be needed to explain our cladogram, irrespective of the cichlid scenario (Figure 2). Host-switching [153], even between fish hosts that differ at the ordinal level [154], as well as substantial salinity tolerance within species [155] have been observed in Monogenea. Although both have mainly been demonstrated in gyrodactylids, even representatives of the ancyrocephalid Cichlidogyrus were suggested to colonize Cyprinodontiformes as a result of ecological transfer from cichlid hosts [156]. Transfer of marine parasites to cichlids is proposed by Pérez-Ponce de Léon and Choudhury [59] to explain the acquisition of additional parasites (cryptogonimid Digenea) after the cichlid's colonization of Mexico. The authors invoke the salinity tolerance of those cichlids, allowing ecological contact with marine or estuarine fishes and, hence, host-switch events. Another example, for cichlids cultured under marine conditions, is provided by Kaneko et al. [123], reporting the acquisition of the marine capsalid monogeneans Neobenedenia melleni (MacCallum, 1927) and Benedenia monticelli (Parona and Perugia, 1895) by Oreochromis mossambicus (Peters, 1852) and O. aureus (Steindachner, 1864), respectively. Those authors mention less-than-optimal adaptation to marine conditions as cause for the susceptibility of the cichlids to a parasite not normally adapted to those hosts, although $N$. melleni has a rather wide host range anyway.

Hence, freshwater/marine transfers are possible and a marine environment lowering the cichlid's condition could ease the colonization by parasites not specialised in cichlids. In favour of the dispersal hypothesis, one could argue that marine migration, freeing cichlids of other ectoparasitic Monogenea and hence removing interspecific competition, would be an additional facilitating factor for ecological transfer. However, it is often assumed that interspecific competition is not such an issue in Monogenea [157-159]. Freshwater/marine transitions would seem to contradict the above-mentioned limited tolerance to osmotic shocks. However, those ecological transfers across salinity borders should be thought of mostly on an evolutionary timescale, and as a feature occurring in certain genera with a broad salinity tolerance ([100] for Protogyrodactylus), rather than as frequent events in a monogenean lifespan.

5.3. A Putative Scenario Assuming the Dispersal Hypothesis. The Gondwanan vicariance hypothesis implies isolation of 
fish populations remaining in their respective freshwater environments. In contrast, in case the present-day distribution pattern of the radiation of cichlids would be the result of dispersal, the hypothesis of Murray [25] applied to their parasites gives us the following scenario. We do not mean to say that the current evidence unequivocally points in this direction; we only outline this scenario as a "thought experiment" as it could explain the present continental differences between cichlid fish parasites. It should also be clear that, whatever the nature of the intercontinental migrations, the present-day cichlid distribution is a result of both vicariance and dispersal. For instance, intracontinental migrations (through freshwater systems) have happened in either case, and have caused the ectoparasites to display a substantial similarity across the respective continents.

(1) If Madagascar is indeed the centre of origin of Cichlidae, Insulacleidus probably represents the only extant representative of the most basal clade of ectoparasitic Monogenea associated to this fish family. In view of the very simple morphology of its haptoral hard parts, this seems an acceptable assumption.

(2) Two marine migrations from this island took place in the late Cretaceous (50-55 MYA [25]), one towards Asia, and another one towards Africa, leading to putative loss of all Malagasy ectoparasites and subsequent infection by parasites of different host families in the new continent. This created the current differences in ectoparasitic fauna between the continents (Figure 1). Mesoparasites, however, were retained during marine migrations. The difference observed for these parasites (Enterogyrus spp.) is the result of simple isolation-by-distance. If this were the case, no reproduction would have occurred (or been required) during the migration. Salinity would have posed an obstacle to reinfection during the migration because monogenean larvae (oncomiracidia) are free-living organisms and would not survive this salinity change. The retention of mesoparasites would have been possible, however, if the migrations occurred quickly, allowing the individual adult parasites of migrating hosts to survive the migration. It is important to note that Enterogyrus, just like Urogyrus, is only known from cichlid hosts [78]. There is, hence, no reason to assume that the presence of representatives of this genus on different continents is a consequence of host-switch from other hosts.

(3) A second migration through marine waters took place between West Africa and South America (20 MYA [25]), with the same consequences as above: loss of African ectoparasites, infestation of newly arrived "clean" hosts by South American ectoparasites coming from other host families. The time for migration (from Africa to America) was estimated (based on palaeoreconstructions and with dispersal through the aid of oceanic currents and shallow water areas) at 23 days [25], which is compatible with the survival of mesoparasites without reproduction (cfr. supra). This implies that Enterogyrus, or a closely related sister clade, might be present in South American cichlids (the only observation of this genus in the Americas is from an introduced African species [117]). Furthermore, even without having to invoke open-oceanic migration, northern landbridges and stretches of less saline seas provided dispersal pathways for freshwater fishes between Europe and the Americas during the late Cretaceous and Tertiary [13]. Thus, the cichlid fossils of Europe ([25]; cfr. infra) could fit well in this hypothesis. Also, the still ongoing debate on whether the salinity tolerance of cichlids suffices for oceanic migration would pose no problem here, as dispersal over landbridges or through diluted marine or coastal environments would not require them to withstand marine openwater conditions. In fact, it seems harder to find a plausible dispersal path for cichlids towards Asia. In contrast, for Mastacembelidae, a fish family with an African-Asian distribution where palaeontological and molecular evidence are in favour of dispersal rather than vicariance, a land bridge (over the Middle East) rather than marine migration is suggested as pathway [160]. The Middle East is also known as a centre of exchange for other freshwater fishes, for example, in cyprinids [161].

(4) Intracontinental migrations lead to the wider colonization of Africa and South America. As these migrations occurred only in freshwaters, there were no losses of parasites, and the parasite fauna now observed is remarkably homogeneous. MendozaFranco and Vidal-Martínez [162] propose an example of this, in Sciadicleithrum, which would have migrated with its cichlid hosts from South to Central America after the uplift of the Panama Isthmus. An exception for Africa is Onchobdella, only infecting hosts with a distribution limited to West Africa (though its mesoparasitic putative sister Urogyrus is more widespread in the continent, $c f r$. supra). In view of Figure 2, their ancestor probably colonized cichlids after lateral transfer from another fish host family.

(5) During the African or American intracontinental expansion of the Cichlidae, three lineages isolate themselves: one colonized the Levant (35 MYA [25]), another one Iran, and the last one North America (Rio Grande river, where Herichthys cyanoguttatus Baird and Girard, 1854 presently occurs [163]).

In her paper, Murray [25] does not conclude whether those fishes migrated through marine or freshwater systems (Figure 3, black and white striped arrows). As Levantine cichlid parasites (ecto- and meso-) are similar to African ones, we suppose that the migrations which introduced this fish family to this area solely involved crossing freshwaters (for otherwise, the ectoparasitic fauna should be different). While Werner and Mokady [164] suggest much more recent colonisation for the only Levantine haplochromine, Astatotilapia flaviijosephi (Lortet, 1883), they do not 
invoke marine dispersal for its arrival from Africa into the Levant either.

For the Iranian or North American colonization, we should be able to assess the likelihood of marine or freshwater migration by describing ectoparasites from those cichlid species. Ancyrocephalidae have hitherto not been found on them; only 20 specimens, provided by B. Jalali, of Iranocichla hormuzensis have been studied, yielding only gyrodactylid monogeneans (A. Pariselle, unpublished data). No data were available for Rio Grande fishes. In both cases (Iran and North America) Enterogyrus (or a related genus-being a mesoparasite) should be present.

(6) The presence of cichlid fossils is demonstrated in Europe (Italy) and Central America (Haiti). As these faunas are extinct, their parasites will remain unknown and their migration pathways cannot be inferred from host-parasite data (Figure 3, grey arrows).

\section{Conclusions and Suggested Approach}

The current knowledge on diversity and distribution of parasites does not allow us to be conclusive in supporting either the dispersal or vicariance hypothesis explaining the present-day distribution of cichlids. The interesting outcome of analysing the parasite data is that the resulting conclusions may be tested and falsified. Although the presence of Enterogyrus on cichlid hosts worldwide (i.e., in South America and/ or Madagascar) has not been demonstrated yet, the most crucial argument here could be provided by a sound phylogeny of dactylogyridean ectoparasites of cichlids (for which the data are currently lacking). In view of classical problems in molecular phylogenetic reconstruction, such as introgression [165] and discordance between conclusions based on mitochondrial versus nuclear markers [166], multigene approaches are recommended. One should examine, using molecular phylogenetics, whether there consistently is a closer relationship between Asian, African, or South American cichlid ectoparasites with other ectoparasites from different local host families, than with the parasites of cichlid hosts on other continents. Apart from sistergroup relations, genetics could also give us clues on the evolutionary distances between the various cichlid monogeneans. This is crucial, as the mesoparasite Enterogyrus could have a slower rate of evolution and diversification than the various ectoparasitic genera (perhaps due to high constraints resulting from its mesoparasitic lifestyle), possibly explaining the higher diversity in ecto- than in mesoparasites. Though little molecular evolutionary data exist of these animals, results of Mendlová et al. [100] do not support this hypothesis. Moreover, ectoparasitic Monogenea may depend for their speciation on their hosts' diversification ([167] but see [168]), making a speciation burst independent of cichlid history unlikely. Furthermore, mesoparasitism is a derived and polyphyletic feature in our cladogram (and a derived character in the phylogeny of Mendlová et al. [100]), so there is little reason to assume that those parasites in general evolve in a different way from their ectoparasitic counterparts.

Finally, we hope to have exemplified that the evolution and biogeography of parasites should be considered in association with a sound knowledge of their hosts. Indeed, Murray's theory on age and dispersal pattern of cichlids could be in agreement with their continent-specific fauna of ectoparasitic Monogenea, though extra (molecular) data are evidently needed to be conclusive. Conversely, we have to keep in mind the contribution that the study of parasites can make to investigations concerning their hosts, at different levels. This spans from the most specific, where parasites can assist in the identification of host sister species [74, 169], up to the broadest, as in the example presented here, where parasites might lead us to choose between two hypotheses on host origin. On an intermediate level, parasites might resolve an ambiguity on the mode of cichlid biogeographical evolution: for example, that the Levantine migration occurred by crossing freshwater rather than marine systems.

\section{Appendix}

(1) Hook: shank tapering proximally; shank with bulb at proximal end. (2) Hooks: similar in shape and size; hook 5 almost splinter-like; greatly variable in size. (3) Thumbs of hooks: erected; straight; depressed. (4) Number of distinct portions in hook shank: one; two. (5) Ventral anchor: fully developed; splinter-like; one fully developed, another splinter-like. (6) Ventral bar-anterior margin: without obvious ornamentation; with subterminal flaps; with large shield-like plate; with small flap. (7) Ventral bar shape: straight; Vshaped; inverted V-shaped; arched. (8) Longitudinal groove on ventral bar: absent; present. (9) Dorsal bar: single; double; absent. (10) Dorsal bar-subterminal anterior flaps: absent; present, well developed and supported by ridges; present, no supporting ridges. (11) Dorsal bar-anterior auricles: absent; present. (12) Dorsal bar: straight or slightly Vshaped; M-shaped; inverted V-shaped. (13) Accessory piece: present; absent. (14) Male copulatory organ: coiled; somewhat straight or straight. (15) Articulation of copulatory complex: articulated; nonarticulated. (16) Vagina: ventral; dextrolateral; sinistrolateral. (17) Vagina: sclerotized; nonsclerotized.

\section{Acknowledgments}

M. P. M. Vanhove is in receipt of a Ph.D. fellowship of the Research Foundation-Flanders (FWO-Vlaanderen). W. A. Boeger is a research fellow of CNPq-Brazil. The authors wish to thank A. M. Murray, M. R. Deveney, D. C. Kritsky, and L. Euzet for comments on an earlier version of this paper, D. F. E. Thys van den Audenaerde for useful suggestions, and J. Cable and B. Jalali for providing A. Pariselle with cichlid specimens. The authors also acknowledge the ANR IFORA. S. Koblmüller and four anonymous reviewers contributed significantly to the improvement of this paper. 


\section{References}

[1] M. Vences, D. R. Vieites, F. Glaw et al., "Multiple overseas dispersal in amphibians," Proceedings of the Royal Society B: Biological Sciences, vol. 270, no. 1532, pp. 2435-2442, 2003.

[2] B. Hugueny, "West African rivers as biogeographic islands: species richness of fish communities," Oecologia, vol. 79, no. 2, pp. 236-243, 1989.

[3] J. Heino, "Regional gradient analysis of freshwater biota: do similar biogeographic patterns exist among multiple taxonomic groups?" Journal of Biogeography, vol. 28, no. 1, pp. 69-76, 2001.

[4] R. M. McDowall, "Accumulating evidence for a dispersal biogeography of southern cool temperate freshwater fishes," Journal of Biogeography, vol. 29, no. 2, pp. 207-219, 2002.

[5] A. D. Yoder and M. D. Nowak, "Has vicariance or dispersal been the predominant biogeographic force in Madagascar? Only time will tell," Annual Review of Ecology, Evolution, and Systematics, vol. 37, pp. 405-431, 2006.

[6] A. de Queiroz, "The resurrection of oceanic dispersal in historical biogeography," Trends in Ecology and Evolution, vol. 20, no. 2, pp. 68-73, 2005.

[7] T. M. Berra, Freshwater Fish Distribution, Academic Press, San Diego, Calif, USA, 2001.

[8] S. T. Hertwig, "Phylogeny of the Cyprinodontiformes (Teleostei, Atherinomorpha): the contribution of cranial soft tissue characters," Zoologica Scripta, vol. 37, no. 2, pp. 141-174, 2008.

[9] J. C. Briggs, "Fishes and birds: Gondwana life rafts reconsidered," Systematic Biology, vol. 52, no. 4, pp. 548-553, 2003.

[10] A. M. Zanata and R. P. Vari, "The family Alestidae (Ostariophysi, Characiformes): a phylogenetic analysis of a transAtlantic clade," Zoological Journal of the Linnean Society, vol. 145, no. 1, pp. 1-144, 2005.

[11] D. Calcagnotto, S. A. Schaefer, and R. DeSalle, "Relationships among characiform fishes inferred from analysis of nuclear and mitochondrial gene sequences," Molecular Phylogenetics and Evolution, vol. 36, no. 1, pp. 135-153, 2005.

[12] J. P. Sullivan, J. G. Lundberg, and M. Hardman, "A phylogenetic analysis of the major groups of catfishes (Teleostei: Siluriformes) using rag1 and rag2 nuclear gene sequences," Molecular Phylogenetics and Evolution, vol. 41, no. 3, pp. 636$662,2006$.

[13] Lundberg J. G., J. P. Sullivan, R. Rodiles-Hernández, and D. A. Hendrickson, "Discovery of African roots for the Mesoamerican Chiapas catfish, Lacantunia enigmatica, requires an ancient intercontinental passage," Proceedings of the Academy of Natural Sciences of Philadelphia, vol. 156, pp. 39-53, 2007.

[14] H. Brinkhuis, S. Schouten, M. E. Collinson et al., "Episodic fresh surface waters in the Eocene Arctic Ocean," Nature, vol. 441, no. 7093, pp. 606-609, 2006.

[15] P. Chakrabarty, "Cichlid biogeography: comment and review," Fish and Fisheries, vol. 5, no. 2, pp. 97-119, 2004.

[16] J. S. Sparks and W. L. Smith, "Freshwater fishes, dispersal ability, and nonevidence: "Gondwana life rafts" to the rescue," Systematic Biology, vol. 54, no. 1, pp. 158-165, 2005.

[17] Y. Azuma, Y. Kumazawa, M. Miya, K. Mabuchi, and M. Nishida, "Mitogenomic evaluation of the historical biogeography of cichlids toward reliable dating of teleostean divergences," BMC Evolutionary Biology, vol. 8, no. 1, article 215, 2008.

[18] M. Stiassny, "Cichlid familial intrarelationships and the placement of the neotropical genus Cichla (Perciformes,
Labroidei)," Journal of Natural History, vol. 21, no. 5, pp. 1311-1331, 1987.

[19] R. Zardoya, D. M. Vollmer, C. Craddock, J. T. Streelman, S. Karl, and A. Meyer, "Evolutionary conservation of microsatellite flanking regions and their use in resolving the phylogeny of cichlid fishes (Pisces: Perciformes)," Proceedings of the Royal Society B: Biological Sciences, vol. 263, no. 1376, pp. 1589-1598, 1996.

[20] J. T. Streelman, R. Zardoya, A. Meyer, and S. A. Karl, "Multilocus phylogeny of cichlid fishes (Pisces: Perciformes): evolutionary comparison of microsatellite and single-copy nuclear loci," Molecular Biology and Evolution, vol. 15, no. 7, pp. 798-808, 1998.

[21] I. P. Farias, G. Ortí, I. Sampaio, H. Schneider, and A. Meyer, "Mitochondrial DNA phylogeny of the family Cichlidae: monophyly and fast molecular evolution of the neotropical assemblage," Journal of Molecular Evolution, vol. 48, no. 6, pp. 703-711, 1999.

[22] I. P. Farias, G. Ortí, and A. Meyer, “Total evidence: molecules, morphology, and the phylogenetics of cichlid fishes," Journal of Experimental Zoology, vol. 288, no. 1, pp. 76-92, 2000.

[23] Y. Kumazawa, M. Yamaguchi, and M. Nishida, "Mitochondrial molecular clocks and the origin of euteleostean biodiversity: familial radiation of Perciformes may have predated the Cretaceous/Tertiary boundary," in The Biology of Biodiversity, M. Kato, Ed., pp. 35-52, Springer, Tokyo, Japan, 2000.

[24] A. M. Murray, "The palaeozoic, mesozoic and early cenozoic fishes of Africa," Fish and Fisheries, vol. 1, pp. 111-145, 2000.

[25] A. M. Murray, "The fossil record and biogeography of the Cichlidae (Actinopterygii: Labroidei)," Biological Journal of the Linnean Society, vol. 74, no. 4, pp. 517-532, 2001.

[26] M. Vences, J. Freyhof, R. Sonnenberg, J. Kosuch, and M. Veith, "Reconciling fossils and molecules: cenozoic divergence of cichlid fishes and the biogeography of Madagascar," Journal of Biogeography, vol. 28, no. 9, pp. 1091-1099, 2001.

[27] J. S. Sparks, "Molecular phylogeny and biogeography of the Malagasy and South Asian cichlids (Teleostei: Perciformes: Cichlidae)," Molecular Phylogenetics and Evolution, vol. 30, no. 3, pp. 599-614, 2004.

[28] J. S. Sparks and W. L. Smith, "Phylogeny and biogeography of cichlid fishes (Teleostei: Perciformes: Cichlidae)," Cladistics, vol. 20, no. 6, pp. 501-517, 2004.

[29] M. J. Genner, O. Seehausen, D. H. Lunt et al., "Age of cichlids: new dates for ancient lake fish radiations," Molecular Biology and Evolution, vol. 24, no. 5, pp. 1269-1282, 2007.

[30] S. O. Kullander, "A phylogeny and classification of the South American Cichlidae (Teleostei: Perciformes)," in Phylogeny and Classification of Neotropical Fishes, L. R. Malabarba, R. E. Reis, R. P. Vari, Z. M. Lucena, and C. A. S. Lucena, Eds., pp. 461-498, Edipucrs, Porto Alegre, Brazil, 1998.

[31] P. Chakrabarty, "Systematics and historical biogeography of greater Antillean Cichlidae," Molecular Phylogenetics and Evolution, vol. 39, no. 3, pp. 619-627, 2006.

[32] G. A. Concheiro Pérez, O. Ríčan, G. Ortí, E. Bermingham, I. Doadrio, and R. Zardoya, "Phylogeny and biogeography of 91 species of heroine cichlids (Teleostei: Cichlidae) based on sequences of the cytochrome $b$ gene," Molecular Phylogenetics and Evolution, vol. 43, no. 1, pp. 91-110, 2007.

[33] M. L. J. Stiassny, "Phylogenetic intrarelationships of the family Cichlidae: an overview," in Cichlid Fishes: Behaviour, Ecology and Evolution, M. H. A. Keenleyside, Ed., pp. 1-35, Chapman \& Hall, London, UK, 1991. 
[34] V. Klett and A. Meyer, "What, if anything, is a Tilapia? Mitochondrial ND2 phylogeny of tilapiines and the evolution of parental care systems in the African cichlid fishes," Molecular Biology and Evolution, vol. 19, no. 6, pp. 865-883, 2002.

[35] S. B. Hedges and S. Kumar, "Precision of molecular time estimates," Trends in Genetics, vol. 20, no. 5, pp. 242-247, 2004.

[36] D. Graur and W. Martin, "Reading the entrails of chickens: molecular timescales of evolution and the illusion of precision," Trends in Genetics, vol. 20, no. 2, pp. 80-86, 2004.

[37] R. R. Reisz and J. Müller, "Molecular timescales and the fossil record: a paleontological perspective," Trends in Genetics, vol. 20, no. 5, pp. 237-241, 2004.

[38] J. G. Lundberg, "African-South American freshwater fish clades and continental drift: problems with a paradigm," in Biological Relationships between Africa and South America, P. Goldblatt, Ed., pp. 156-198, Yale University, New Haven, Conn, USA, 1993.

[39] H. W. Manter, "Parasites of fishes as biological indicators of recent and ancient conditions," in Host Parasite Relationships, J. E. McCauley, Ed., pp. 59-71, Oregon State University, Corvallis, Ore, USA, 1966.

[40] A. O. Bush, J. C. Fernández, G. W. Esch, and J. R. Seed, Parasitism. The Diversity and Ecology of Animal Parasites, Cambridge University, Cambridge, UK, 2001.

[41] C. Combes, Parasitism. The Ecology and Evolution of Intimate Interactions, University of Chicago, Chicago, Ill, USA, 2001.

[42] C. M. Nieberding and I. Olivieri, "Parasites: proxies for host genealogy and ecology?" Trends in Ecology and Evolution, vol. 22, no. 3, pp. 156-165, 2007.

[43] E. P. Hoberg, "Phylogeny and historical reconstitution: hostparasite systems as keystones in biogeography and ecology," in Biodiversity II, M. L. Reaka-Kulda, D. E. Wilson, and E. O. Wilson, Eds., pp. 243-261, Joseph Henry, Washington, DC, USA, 1997.

[44] D. R. Brooks, "Hennig's parasitological method: a proposed solution," Systematic Zoology, vol. 30, no. 3, pp. 229-249, 1981.

[45] G. Nelson and N. I. Platnick, Systematics and Biogeography: Cladistics and Vicariance, Columbia University, New York, NY, USA, 1981.

[46] J. Cracraft, "Geographic differentiation, cladistics, and vicariance biogeography: reconstructing the tempo and mode of evolution," American Zoologist, vol. 22, no. 2, pp. 411-424, 1982.

[47] K. Rohde, "Zoogeography of marine parasites," Helgoländer Meeresuntersuchungen, vol. 37, no. 1-4, pp. 35-52, 1984.

[48] K. Rohde, "Ecology and biogeography of marine parasites," Advances in Marine Biology, vol. 43, pp. 1-83, 2002.

[49] D. R. Glen and D. R. Brooks, "Parasitological evidence pertaining to the phylogeny of the hominoid primates," Biological Journal of the Linnean Society, vol. 27, no. 4, pp. 331-354, 1986.

[50] E. O. Wiley, "Vicariance biogeography," Annual Review of Ecology and Systematics, vol. 19, pp. 513-542, 1988.

[51] G. J. Klassen, "Coevolution: a history of the macroevolutionary approach to studying host- parasite associations," Journal of Parasitology, vol. 78, no. 4, pp. 573-587, 1992.

[52] F. Thomas, O. Verneau, T. de Meeûs, and F. Renaud, "Parasites as to host evolutionary prints: insights into host evolution from parasitological data," International Journal for Parasitology, vol. 26, no. 7, pp. 677-686, 1996.

[53] J. N. Caira and L. Euzet, "Age of association between the nurse shark, Ginglymostoma cirratum, and tapeworms of the genus Pedibothrium (Tetraphyllidea: Onehobothriidae): implications from geography," Biological Journal of the Linnean Society, vol. 72, no. 4, pp. 609-614, 2001.

[54] E. P. Hoberg and G. J. Klassen, "Revealing the faunal tapestry: co-evolution and historical biogeography of hosts and parasites in marine systems," Parasitology, vol. 124, no. 7, pp. S3-S22, 2002.

[55] E. P. Hoberg and D. R. Brooks, "Beyond vicariance: integrating taxon pulses, ecological fitting, and oscillation in evolution and historical biogeography," in The Biogeography of Host-Parasite Interactions, S. Morand and B. R. Krasnov, Eds., pp. 7-20, Oxford University, Oxford, UK, 2010.

[56] R. M. McDowall, "Biogeography of the southern cool-temperate galaxioid fishes: evidence from metazoan macroparasite faunas," Journal of Biogeography, vol. 27, no. 5, pp. 12211229, 2000.

[57] A. Choudhury and T. A. Dick, "Sturgeons (Chondrostei: Acipenseridae) and their metazoan parasites: patterns and processes in historical biogeography," Journal of Biogeography, vol. 28, no. 11-12, pp. 1411-1439, 2001.

[58] R. Aguilar-Aguilar, R. Contreras-Medina, and G. SalgadoMaldonado, "Parsimony analysis of endemicity (PAE) of Mexican hydrological basins based on helminth parasites of freshwater fishes," Journal of Biogeography, vol. 30, no. 12, pp. 1861-1872, 2003.

[59] G. Pérez-Ponce de León and A. Choudhury, "Biogeography of helminth parasites of freshwater fishes in Mexico: the search for patterns and processes," Journal of Biogeography, vol. 32, no. 4, pp. 645-659, 2005.

[60] C. Nieberding, S. Morand, R. Libois, and J. R. Michaux, "A parasite reveals cryptic phylogeographic history of its host," Proceedings of the Royal Society B: Biological Sciences, vol. 271, no. 1557, pp. 2559-2568, 2004.

[61] C. D. Criscione, B. Cooper, and M. S. Blouin, "Parasite genotypes identify source populations of migratory fish more accurately than fish genotypes," Ecology, vol. 87, no. 4, pp. 823-828, 2006.

[62] A. M. H. Blakeslee, J. E. Byers, and M. P. Lesser, "Solving cryptogenic histories using host and parasite molecular genetics: the resolution of Littorina littorea's North American origin," Molecular Ecology, vol. 17, no. 16, pp. 3684-3696, 2008.

[63] W. Hennig, Phylogenetic Systematics, University of Illinois, Urbana, Ill, USA, 1966.

[64] E. O. Wiley, Phylogenetics: The Theory and Practice of Phylogenetic Analysis, John Wiley and Sons, New York, NY, USA, 1981.

[65] D. R. Brooks and R. T. O'Grady, "Crocodilians and their helminth parasites: macroevolutionary considerations," American Zoologist, vol. 29, no. 3, pp. 873-883, 1989.

[66] E. O. Wiley, D. Siegel-Causey, D. R. Brooks, and V. A. Funk, The Compleat Cladist: A Primer of Phylogenetic Procedures, University of Kansas Museum of Natural History, Lawrence, Kan, USA, 1991.

[67] R. D. M. Page and E. C. Holmes, Molecular Evolution: A Phylogenetic Approach, Blackwell Science, Malden, Mass, USA, Oxford, UK and Carlton, Australia, 1998.

[68] L. Plaisance, V. Rousset, S. Morand, and D. T. J. Littlewood, "Colonization of Pacific islands by parasites of low dispersal ability: phylogeography of two monogenean species parasitizing butterflyfishes in the South Pacific Ocean," Journal of Biogeography, vol. 35, no. 1, pp. 76-87, 2008.

[69] W. A. Boeger and D. C. Kritsky, "Parasites, fossils and geologic history: Historical biogeography of the South American 
freshwater croakers, Plagioscion spp. (Teleostei, Sciaenidae)," Zoologica Scripta, vol. 32, no. 1, pp. 3-11, 2003.

[70] M. Barson, I. Přikrylová, M. P. M. Vanhove, and T. Huyse, "Parasite hybridization in African Macrogyrodactylus spp. (Monogenea, Platyhelminthes) signals historical host distribution," Parasitology, vol. 137, no. 10, pp. 1585-1595, 2010.

[71] J. F. Guégan and A. Lambert, "Twelve new species of dactylogyrids (Platyhelminthes, Monogenea) from West African barbels (Teleostei, Cyprinidae), with some biogeographical implications," Systematic Parasitology, vol. 17, no. 3, pp. 153181, 1990.

[72] L. R. Van Every and D. C. Kritsky, "Neotropical Monogenoidea. 18. Anacanthorus Mizelle and Price, 1965 (Dactylogyridae, Anacanthorinae) of piranha (Characoidea, Serrasalmidae) from the Central Amazon, their phylogeny, and aspects of host-parasite coevolution," Journal of the Helminthological Society of Washington, vol. 59, pp. 52-75, 1992.

[73] A. Pariselle, Diversité, spéciation et évolution des Monogènes branchiaux de Cichlidae en Afrique de l'Ouest, Ph.D. thesis, University of Perpignan, Perpignan, France, 1996.

[74] D. Paugy, J. F. Guégan, and J. F. Agnèse, "Three simultaneous and independent approaches to the characterization of a new species of Labeo (Teleostei, Cyprinidae) from West Africa," Canadian Journal of Zoology, vol. 68, pp. 1124-1131, 1990.

[75] A. Pariselle, S. Morand, M. Deveney, and L. Pouyaud, "Parasite species richness of closely related hosts: historical scenario and "genetic" hypothesis," in Taxonomy, Ecology and Evolution of Metazoan Parasites, C. Combes and J. Jourdan, Eds., pp. 147-166, Presses Universitaires de Perpignan, Perpignan, France, 2003.

[76] R. Poulin, "Determinants of host-specificity in parasites of freshwater fishes," International Journal for Parasitology, vol. 22, no. 6, pp. 753-758, 1992.

[77] M. L. Adamson and J. N. Caira, "Evolutionary factors influencing the nature of parasite specificity," Parasitology, vol. 109, pp. S85-S95, 1994.

[78] A. Pariselle and L. Euzet, "Systematic revision of dactylogyridean parasites (Monogenea) from cichlid fishes in Africa, the Levant and Madagascar," Zoosystema, vol. 31, no. 4, pp. 849-898, 2009.

[79] E. F. Mendoza-Franco, T. Scholz, and P. Rozkošná, “Tucunarella $\mathrm{n}$. gen. and other dactylogyrids (Monogenoidea) from cichlid fish (Perciformes) from Peruvian Amazonia," Journal of Parasitology, vol. 96, no. 3, pp. 491-498, 2010.

[80] M. V. Domingues and W. A. Boeger, "Phylogeny and revision of Diplectanidae Monticelli, 1903 (Platyhelminthes: Monogenoidea)," Zootaxa, vol. 1698, pp. 1-40, 2008.

[81] E. M. Perkins, S. C. Donnellan, T. Bertozzi, L. A. Chisholm, and I. D. Whittington, "Looks can deceive: molecular phylogeny of a family of flatworm ectoparasites (Monogenea: Capsalidae) does not reflect current morphological classification," Molecular Phylogenetics and Evolution, vol. 52, no. 3, pp. 705-714, 2009.

[82] M. P. M. Vanhove, J. Snoeks, F. A. M. Volckaert, and T. Huyse, "First description of monogenean parasites in lake Tanganyika: the cichlid Simochromis diagramma (Teleostei, Cichlidae) harbours a high diversity of Gyrodactylus species (Platyhelminthes, Monogenea)," Parasitology, vol. 138, no. 3, pp. 364-380, 2011.

[83] I. Paperna, "Monogenea of inland water fish in Africa," Annalen Koninklijk Museum voor Midden-Afrika Zoologische Wetenschappen, vol. 226, 1979.
[84] S. Rakotofiringa and L. Euzet, "Monogènes parasites de Cichlidae (Teleostei) endémiques de Madagascar," Bulletin de la Société Zoologique de France, vol. 108, pp. 107-114, 1983.

[85] D. C. Kritsky, V. M. Vidal-Martinez, and R. Rodriguez-Canul, "Neotropical monogenoidea. 19. Dactylogyridae of cichlids (Perciformes) from the Yucatan Peninsula, with descriptions of three new species of Sciadicleithrum Kritsky, Thatcher, and Boeger, 1989," Journal of the Helminthological Society of Washington, vol. 61, no. 1, pp. 26-33, 1994.

[86] W. A. Boeger and F. Popazoglo, "Neotropical Monogenoidea. 23. Two new species of Gyrodactylus (Gyrodactylidae) from a cichlid and an erythrinid fish of Southeastern Brazil," Memórias do Instituto Oswaldo Cruz, vol. 90, no. 6, pp. 689694, 1995.

[87] A. Kohn and S. C. Cohen, "South American MonogeneaList of species, hosts and geographical distribution," International Journal for Parasitology, vol. 28, no. 10, pp. 1517-1554, 1998.

[88] K. W. Christison, A. P. Shinn, and J. G. van As, “Gyrodactylus thlapi n. sp. (Monogenea) from Pseudocrenilabrus philander philander (Weber) (Cichlidae) in the Okavango Delta, Botswana," Systematic Parasitology, vol. 60, no. 3, pp. 165173, 2005.

[89] S. C. Cohen and A. Kohn, "South American MonogeneaList of species, hosts and geographical distribution from 1997 to 2008," Zootaxa, vol. 1924, pp. 1-42, 2008.

[90] I. Přikrylová, I. Matějusová, N. Musilová, and M. Gelnar, "Gyrodactylus species (Monogenea: Gyrodactylidae) on the cichlid fishes of Senegal, with the description of Gyrodactylus ergensi n. sp. from Mango tilapia, Sarotherodon galilaeus L. (Teleostei: Cichlidae)," Parasitology Research, vol. 106, no. 1, pp. 1-6, 2009.

[91] L. Euzet, "Ecologie et parasitologie," Bulletin d'Ecologie, vol. 20, pp. 277-280, 1989.

[92] J. Blais, C. Rico, C. van Oosterhout, J. Cable, G. F. Turner, and L. Bernatchez, "MHC adaptive divergence between closely related and sympatric African cichlids," PLoS ONE, vol. 2, no. 8, article e734, 2007.

[93] Kritsky D. C. and W. A. Boeger, "Phylogeny of the Gyrodactylidae and the phylogenetic status of Gyrodactylus Nordmann, 1832 (Platyhelminthes: Monogenoidea)," in Taxonomy, Ecology and Evolution of Metazoan Parasites, C. Combes and J. Jourdan, Eds., pp. 37-58, Presses Universitaires de Perpignan, Perpignan, France, 2003.

[94] P. J. Van Beneden and C. E. Hesse, Recherches sur les Bdellodes ou Hirudinées et les Trématodes Marins, Académie Royale de Belgique, Brussels, Belgium, 1863.

[95] W. A. Boeger, D. C. Kritsky, and M. R. Pie, "Context of diversification of the viviparous Gyrodactylidae (Platyhelminthes, Monogenoidea)," Zoologica Scripta, vol. 32, no. 5, pp. 437448, 2003.

[96] M. V. Domingues, Filogenia e taxonomia de Diplectanidae Monticelli, 1903 (Platyhelminthes; Monogenoidea), Ph.D. thesis, Universidade Federal do Paraná, Curitiba, Brazil, 2004.

[97] D. C. Kritsky, K. C. Pandey, N. Agrawal, and S. M. A. Abdullah, "Monogenoids from the gills of spiny eels (Teleostei: Mastacembelidae) in India and Iraq, proposal of Mastacembelocleidus gen. n., and status of the Indian species of Actinocleidus, Urocleidus and Haplocleidus (Monogenoidea: Dactylogyridae)," Folia Parasitologica, vol. 51, no. 4, pp. 291298, 2004.

[98] N. Agrawal, A. Tripathi, and A. Devak, "Monogeneans from the gills of glassfishes (Teleostei: Perciformes: Ambassidae) in India, with the proposal of Chandacleidus n. g. (Monogenea: 
Dactylogyridae)," Systematic Parasitology, vol. 63, no. 3, pp. 223-230, 2006.

[99] G. P. Viozzi and N. Brugni, "Duplaccessorius andinus n. gen., n. sp. (Dactylogyridae: Ancyrocephalinae) from the gills of Percichthys trucha (Perciformes: Percichthyidae) in Patagonia, Argentina," Journal of Parasitology, vol. 90, no. 5, pp. 966-969, 2004.

[100] M. Mendlová, A. Pariselle, M. Vyskočilová, and A. Šimková, "Molecular phylogeny of monogeneans parasitizing African freshwater Cichlidae inferred from LSU rDNA sequences," Parasitology Research, vol. 107, no. 6, pp. 1405-1413, 2010.

[101] P. Galli and D. C. Kritsky, "Three new species of Protogyrodactylus Johnston \& Tiegs, 1922 (Monogenoidea: Dactylogyridae) from the gills of the longtail silverbiddy Gerres longirostris (Teleostei: Gerreidae) in the Red Sea," Systematic Parasitology, vol. 69, no. 3, pp. 221-231, 2008.

[102] A. Tripathi, N. Agrawal, and K. C. Pandey, "The status of Quadriacanthus Paperna, 1961 and Anacornuatus Dubey et al., 1991 (Monogenoidea: Dactylogyridae) with redescription of Q. kobiensis Ha Ky, 1968, new geographical records for Q. bagrae Paperna, 1979 and Q. clariadis Paperna, 1961 from India and a note on speciation in Monogenoidea," Parasitology International, vol. 56, no. 1, pp. 23-30, 2007.

[103] O. N. Pugachev, P. I. Gerasev, A. V. Gussev, R. Ergens, and I. Khotenowsky, Guide to Monogenoidea of Freshwater Fish of Palaearctic and Amur Regions, Ledizione-LediPublishing, Milan, Italy, 2009.

[104] L. Mariniello, M. Ortis, S. D’Amelio, and V. Petrarca, "Morphometric variability between and within species of Ligophorus Euzet \& Suriano, 1977 (Monogenea: Ancyrocephalidae) in the Mediterranean Sea," Systematic Parasitology, vol. 57, no. 3, pp. 183-190, 2004.

[105] L. H. Du Preez and M. F. Maritz, "Demonstrating morphometric protocols using polystome marginal hooklet measurements," Systematic Parasitology, vol. 63, no. 1, pp. 115, 2006.

[106] T. Poisot and Y. Desdevises, "Putative speciation events in Lamellodiscus (Monogenea: Diplectanidae) assessed by a morphometric approach," Biological Journal of the Linnean Society, vol. 99, no. 3, pp. 559-569, 2010.

[107] L. Pouyaud, E. Desmarais, M. Deveney, and A. Pariselle, "Phylogenetic relationships among monogenean gill parasites (Dactylogyridea, Ancyrocephalidae) infesting tilapiine hosts (Cichlidae): Systematic and evolutionary implications," Molecular Phylogenetics and Evolution, vol. 38, no. 1, pp. 241249, 2006.

[108] M. Vignon, A. Pariselle, and M. P. M. Vanhove, "Modularity in attachment organs of African Cichlidogyrus (Platyhelminthes, Monogenea, Ancyrocephalidae) reflects phylogeny rather than host specificity or geographic distribution," Biological Journal of the Linnean Society, vol. 102, pp. 706-694, 2011.

[109] L. Swofford, PAUP*. Phylogenetic Analysis Using Parsimony (*and Other Methods). Version 4, Sinauer Associates, Sunderland, Mass, USA, 2003.

[110] K. Bremer, "The limits of amino acid sequence data in angiosperm phylogenetic reconstruction," Evolution, vol. 42, pp. 795-803, 1988.

[111] K. Bremer, "Branch support and tree stability," Cladistics, vol. 10, no. 3, pp. 295-304, 1994.

[112] M. Källersjö, J. S. Farris, A. G. Kluge, and C. Bull, "Skewness and permutation," Cladistics, vol. 8, no. 3, pp. 275-287, 1992.

[113] M. D. Sorenson and E. A. Franzosa, TreeRot. Version 3, Boston University, Boston, Mass, USA, 2007.
[114] J. S. Farris, "A successive approximations approach to character weighting," Systematic Zoology, vol. 18, pp. 374385, 1969.

[115] A. G. Kluge and J. S. Farris, "Quantitative phyletics and the evolution of Anurans," Systematic Zoology, vol. 18, pp. 1-32, 1969.

[116] J. S. Farris, "The retention index and the rescaled consistency index," Cladistics, vol. 5, pp. 417-419, 1989.

[117] M. I. Jiménez-García, V. M. Vidal-Martínez, and S. LópezJiménez, "Monogeneans in introduced and native cichlids in México: evidence for transfer," Journal of Parasitology, vol. 87, no. 4, pp. 907-909, 2001.

[118] J. L. Luque and R. Poulin, "Linking ecology with parasite diversity in Neotropical fishes," Journal of Fish Biology, vol. 72, no. 1, pp. 189-204, 2008.

[119] G. S. Myers, "Fresh-water fishes and West Indian zoogeography," Annual Report of the Board of Regents of the Smithsonian Institution, vol. 92, pp. 339-364, 1938.

[120] G. S. Myers, "Salt-tolerance of fresh-water fish groups in relation to zoogeographical problems," Bijdragen tot de Dierkunde, vol. 28, pp. 315-322, 1949.

[121] B. Coad, "A new genus and species of cichlid endemic to southern Iran," Copeia, vol. 1, pp. 28-37, 1982.

[122] J. Chervinsky, "Tilapia zillii (Gervais) in the Mediterranean," Bamidgeh, vol. 39, pp. 133-134, 1987.

[123] J. J. Kaneko II, R. Yamada, J. A. Brock, and R. M. Nakamura, "Infection of tilapia, Oreochromis mossambicus (Trewavas), by a marine monogenean, Neobenedenia melleni (MacCallum, 1927) Yamaguti, 1963 in Kaneohe Bay, Hawaii, USA, and its treatment," Journal of Fish Diseases, vol. 11, no. 4, pp. 295-300, 1988.

[124] G. M. Reid, "Ichthyogeography of the Guinea-Congo rain forest, West Africa," Proceedings of the Royal Society of Edinburgh Section B: Biological Sciences, vol. 104, pp. 285312, 1996.

[125] K. E. Carpenter, "Cichlidae. Cichlids," in FAO Species Identification Guide for Fishery Purposes. The Living Marine Resources of the Western Central Pacific, K. E. Carpenter and V. Niem, Eds., vol. 5 of Bony Fishes Part 3 (Menidae to Pomacentridae), pp. 3333-3336, FAO, Rome, Italy, 2001.

[126] G. G. Teugels and D. F. E. Thys van den Audenaerde, "Cichlidae," in The Fresh and Brackish Water Fishes of West Africa, D. Paugy, C. Lévêque, and G. G. Teugels, Eds., vol. 42 of Collection Faune et Flore Tropicales, pp. 521-600, Institut de Recherche pour le Développement, Paris, France, Muséum National d'Histoire Naturelle, Paris, France, and Musée Royal de l'Afrique Centrale, Tervuren, Belgium, 2003.

[127] G. Lemarié, J. F. Baroiller, F. Clota, J. Lazard, and A. Dosdat, "A simple test to estimate the salinity resistance of fish with specific application to O. niloticus and S. melanotheron," Aquaculture, vol. 240, no. 1-4, pp. 575-587, 2004.

[128] K. Riede, Global register of migratory species - from global to regional scales, Final Report of the RandD-Projekt 80805 081, Bonn, Germany, 2004.

[129] P. G. Bianco and F. Nordlie, "The salinity tolerance of Pseudophoxinus stymphalicus (Cyprinidae) and Valencia letourneuxi (Valenciidae) from western Greece suggests a revision of the ecological categories of freshwater fishes," Italian Journal of Zoology, vol. 75, no. 3, pp. 285-293, 2008.

[130] J. Panfili, A. Mbow, J. D. Durand et al., "Influence of salinity on the life-history traits of the West African black-chinned tilapia (Sarotherodon melanotheron): comparison between the Gambia and Saloum estuaries," Aquatic Living Resources, vol. 17, no. 1, pp. 65-74, 2004. 
[131] B. K. Diggles, F. R. Roubal, and R. J. G. Lester, “The influence of formalin, benzocaine and hyposalinity on the fecundity and viability of Polylabroides multispinosus (Monogenea: Microcotylidae) parasitic on the gills of Acanthopagrus australis (Pisces: Sparidae)," International Journal for Parasitology, vol. 23, no. 7, pp. 877-884, 1993.

[132] K. S. Liang and T. S. Leong, "Treatment of cultured golden snapper, Lutjanus johni Bloch, infected with monogeneans," Aquaculture, vol. 106, no. 1, pp. 1-8, 1992.

[133] A. Soleng and T. A. Bakke, "Salinity tolerance of Gyrodactylus salaris (Platyhelminthes, Monogenea): laboratory studies," Canadian Journal of Fisheries and Aquatic Sciences, vol. 54, no. 8, pp. 1837-1845, 1997.

[134] F. J. Stephens, J. J. Cleary, G. Jenkins, J. B. Jones, S. R. Raidal, and J. B. Thomas, "Treatments to control Haliotrema abaddon in the West Australian dhufish, Glaucosoma hebraicum," Aquaculture, vol. 215, no. 1-4, pp. 1-10, 2003.

[135] A. Pariselle and A. Diamanka, "Information on Sarotheradon melanotheron (Cichlidae) provided by monogenean parasites," in 6th International Symposium on Monogenea, Cape Town, South Africa, 2009.

[136] P. D. Olson and D. T. J. Littlewood, "Phylogenetics of the Monogenea-evidence from a medley of molecules," International Journal for Parasitology, vol. 32, no. 3, pp. 233-244, 2002.

[137] M. S. Ziętara and J. Lumme, "Comparison of molecular phylogeny and morphological systematics in fish parasite genus Gyrodactylus Nordmann, 1832 (Monogenea, Gyrodactylidae)," Zoologica Poloniae, vol. 49, pp. 5-28, 2004.

[138] K. Rohde and N. Watson, "Morphology and geographical variation of Pseudokuhnia minor n. g., n. comb. (Monogenea: Polyopisthocotylea)," International Journal for Parasitology, vol. 15, no. 5, pp. 557-567, 1985.

[139] A. Geets, C. Appleby, and F. Ollevier, "Host-dependent and seasonal variation in opisthaptoral hard parts of Gyrodactylus cf. arcuatus from three Pomatoschistus spp. and G. arcuatus from Gasterosteus aculeatus: a multivariate approach," Parasitology, vol. 119, no. 1, pp. 27-40, 1999.

[140] K. Mancheva, E. Karaivanova, G. Atanasov, S. Stojanovski, and I. Nedeva, "Analysis of the influence of the host body size on morphometrical characteristics of Ancylodiscoides siluri and Ancylodiscoides vistulensis," Biotechnology and Biotechnological Equipment, vol. 23, pp. 735-741, 2009.

[141] K. Olstad, L. Bachmann, and T. A. Bakke, "Phenotypic plasticity of taxonomic and diagnostic structures in gyrodactylosis-causing flatworms (Monogenea, Platyhelminthes)," Parasitology, vol. 136, no. 11, pp. 1305-1315, 2009.

[142] M. Bueno-Silva, W. A. Boeger, and M. R. Pie, "Choice matters: incipient speciation in Gyrodactylus corydori (Monogenoidea: Gyrodactylidae)," International Journal for Parasitology, vol. 41, no. 6, pp. 657-667, 2011.

[143] J. Jarkovský, S. Morand, A. Šimková, and J. B. Geller, "Reproductive barriers between congeneric monogenean parasites (Dactylogyrus: Monogenea): attachment apparatus morphology or copulatory organ incompatibility?" Parasitology Research, vol. 92, pp. 105-95, 2004.

[144] A. Šimková and S. Morand, "Co-evolutionary patterns in congeneric monogeneans: a review of Dactylogyrus species and their cyprinid hosts," Journal of Fish Biology, vol. 73, no. 9, pp. 2210-2227, 2008.

[145] M. P. M. Vanhove, F. A. M. Volckaert, and A. Pariselle, "Ancyrocephalidae (Monogenea) of lake Tanganyika: I: four new species of Cichlidogyrus from Ophthalmotilapia ventralis
(Teleostei, Cichlidae), the first record of this family in the basin," Zoologia, vol. 28, no. 2, pp. 253-263, 2011.

[146] C. Havermans, Z. T. Nagy, G. Sonet, C. De Broyer, and P. Martin, "Incongruence between molecular phylogeny and morphological classification in amphipod crustaceans: a case study of Antarctic lysianassoids," Molecular Phylogenetics and Evolution, vol. 55, no. 1, pp. 202-209, 2010.

[147] R. W. Scotland, R. G. Olmstead, and J. R. Bennett, "Phylogeny reconstruction: the role of morphology," Systematic Biology, vol. 52, no. 4, pp. 539-548, 2003.

[148] L. Brocchieri, "Phylogenetic inferences from molecular sequences: review and critique," Theoretical Population Biology, vol. 59, no. 1, pp. 27-40, 2001.

[149] R. A. Jenner, "Accepting partnership by submission? Morphological phylogenetics in a molecular millennium," Systematic Biology, vol. 53, no. 2, pp. 333-342, 2004.

[150] J. J. Wiens, "The role of morphological data in phylogeny reconstruction," Systematic Biology, vol. 53, no. 4, pp. 653661, 2004.

[151] N. D. Smith and A. H. Turner, "Morphology's role in phylogeny reconstruction: perspectives from paleontology," Systematic Biology, vol. 54, no. 1, pp. 166-173, 2005.

[152] O. Rota-Stabelli, L. Campbell, H. Brinkmann et al., "A congruent solution to arthropod phylogeny: phylogenomics, microRNAs and morphology support monophyletic Mandibulata," Proceedings of the Royal Society B: Biological Sciences, vol. 278, no. 1703, pp. 298-306, 2011.

[153] J. Cable, E. C. G. Scott, R. C. Tinsley, and P. D. Harris, "Behavior favoring transmission in the viviparous monogenean Gyrodactylus turnbulli," Journal of Parasitology, vol. 88, no. 1, pp. 183-184, 2002.

[154] T. Huyse, V. Audenaert, and F. A. M. Volckaert, "Speciation and host-parasite relationships in the parasite genus Gyrodactylus (Monogenea, Platyhelminthes) infecting gobies of the genus Pomatoschistus (Gobiidae, Teleostei)," International Journal for Parasitology, vol. 33, no. 14, pp. 1679-1689, 2003.

[155] T. Huyse, C. Pampoulie, V. Audenaert, and F. A. M. Volckaert, "First report of Gyrodactylus spp. (Platyhelminthes: Monogenea) in the western Mediterranean sea: molecular and morphological descriptions," Journal of Parasitology, vol. 92, no. 4, pp. 682-690, 2006.

[156] E. Birgi and L. Euzet, "Monogènes parasites des poissons des eaux douces du Cameroun. Présence des genres Cichlidogyrus et Dactylogyrus chez Aphyosemion (Cyprinodontidae)," Bulletin de la Société Zoologique de France, vol. 108, pp. 101-106, 1983.

[157] K. Rohde, "A non-competitive mechanism responsible for restricting niches," Zoologischer Anzeiger, vol. 1999, no. 3-4, pp. 164-172, 1977.

[158] K. Rohde, "A critical evaluation of intrinsic and extrinsic factors responsible for niche restriction in parasites," American Naturalist, vol. 114, pp. 648-671, 1979.

[159] K. Rohde and P. P. Rohde, "The ecological niches of parasites," in Marine Parasitology, K. Rohde, Ed., pp. 286-293, CABI Publishing, Wallingford, UK, 2005.

[160] K. J. Brown, L. Ruber, R. Bills, and J. J. Day, "Mastacembelid eels support lake Tanganyika as an evolutionary hotspot of diversification," BMC Evolutionary Biology, vol. 10, p. 188, 2010.

[161] J. D. Durand, C. S. Tsigenopoulos, E. Ünlü, and P. Berrebi, "Phylogeny and biogeography of the family cyprinidae in the Middle East inferred from cytochrome $b$ DNA-evolutionary 
significance of this region," Molecular Phylogenetics and Evolution, vol. 22, no. 1, pp. 91-100, 2002.

[162] E. F. Mendoza-Franco and V. M. Vidal-Martínez, "Phylogeny of species of Sciadicleithrum (Monogenoidea: Ancyrocephalinae), and their historical biogeography in the neotropics," Journal of Parasitology, vol. 91, no. 2, pp. 253-259, 2005.

[163] L. M. Page and B. M. Burr, A Field Guide to Freshwater Fishes of North America North of Mexico, Houghton Mifflin Company, Boston, Mass, USA, 1991.

[164] N. Y. Werner and O. Mokady, "Swimming out of Africa: mitochondrial DNA evidence for late Pliocene dispersal of a cichlid from Central Africa to the Levant," Biological Journal of the Linnean Society, vol. 82, no. 1, pp. 103-109, 2004.

[165] D. Rubinoff, "Utility of mitochondrial DNA barcodes in species conservation," Conservation Biology, vol. 20, no. 4, pp. 1026-1033, 2006.

[166] K. L. Shaw, "Conflict between nuclear and mitochondrial DNA phylogenies of a recent species radiation: what mtDNA reveals and conceals about modes of speciation in Hawaiian crickets," Proceedings of the National Academy of Sciences of the United States of America, vol. 99, no. 25, pp. 16122-16127, 2002.

[167] R. Poulin, "Phylogeny, ecology, and the richness of parasite communities in vertebrates," Ecological Monographs, vol. 65, no. 3, pp. 283-302, 1995.

[168] S. Morand, A. Simková, I. Matejusová, L. Plaisance, O. Verneau, and Y. Desdevises, "Investigating patterns may reveal processes: evolutionary ecology of ectoparasitic monogeneans," International Journal for Parasitology, vol. 32, no. 2, pp. 111-119, 2002.

[169] L. Euzet, J. F. Agnèse, and A. Lambert, "Valeur des parasites comme critère d'identification de l'espèce hôte. Démonstration convergente par l'étude parasitologique des monogènes branchiaux et l'analyse génétique des poissons hôtes," Compte Rendu de l'Académie des Sciences de Paris, vol. 308, pp. 385-388, 1989. 

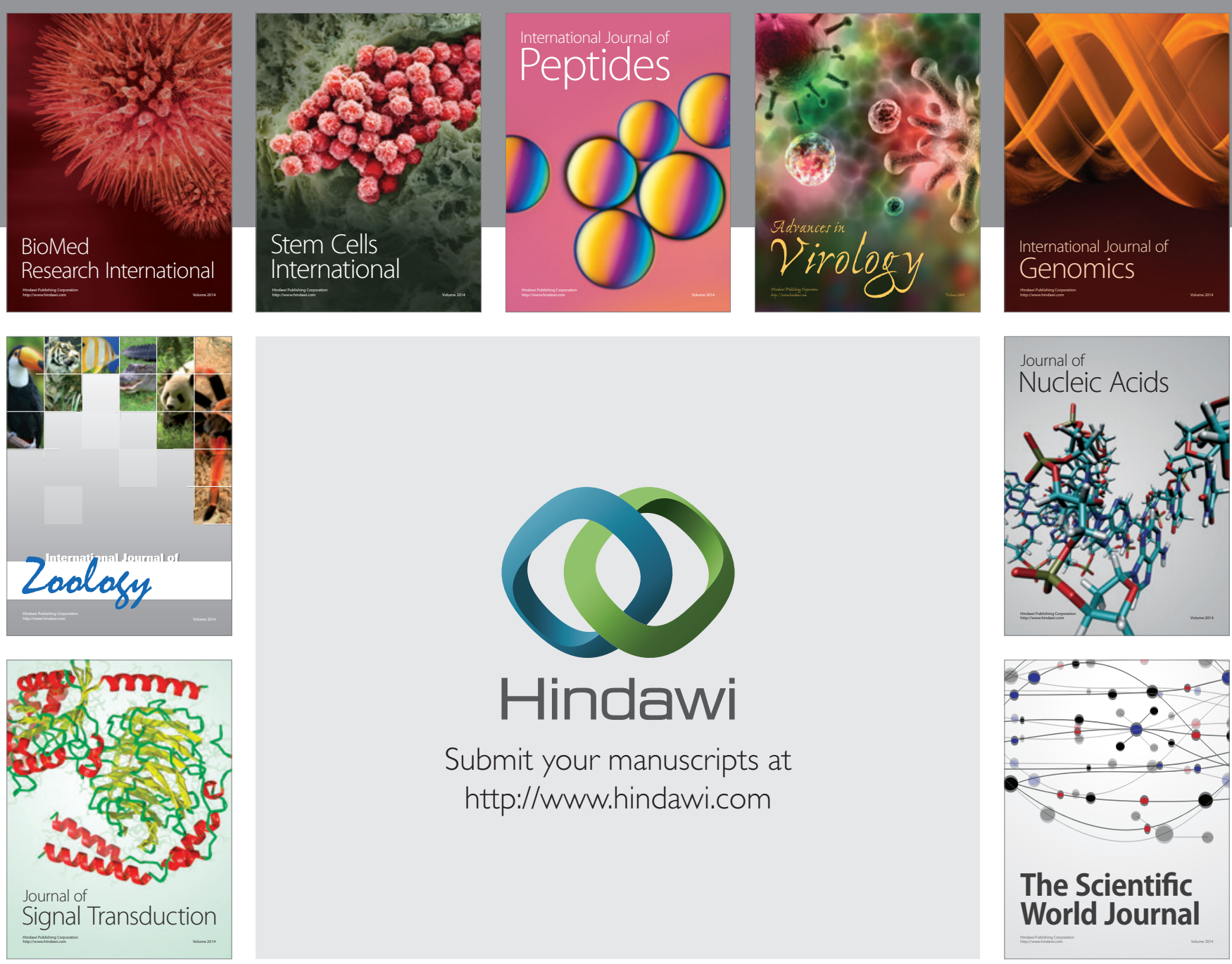

Submit your manuscripts at

http://www.hindawi.com
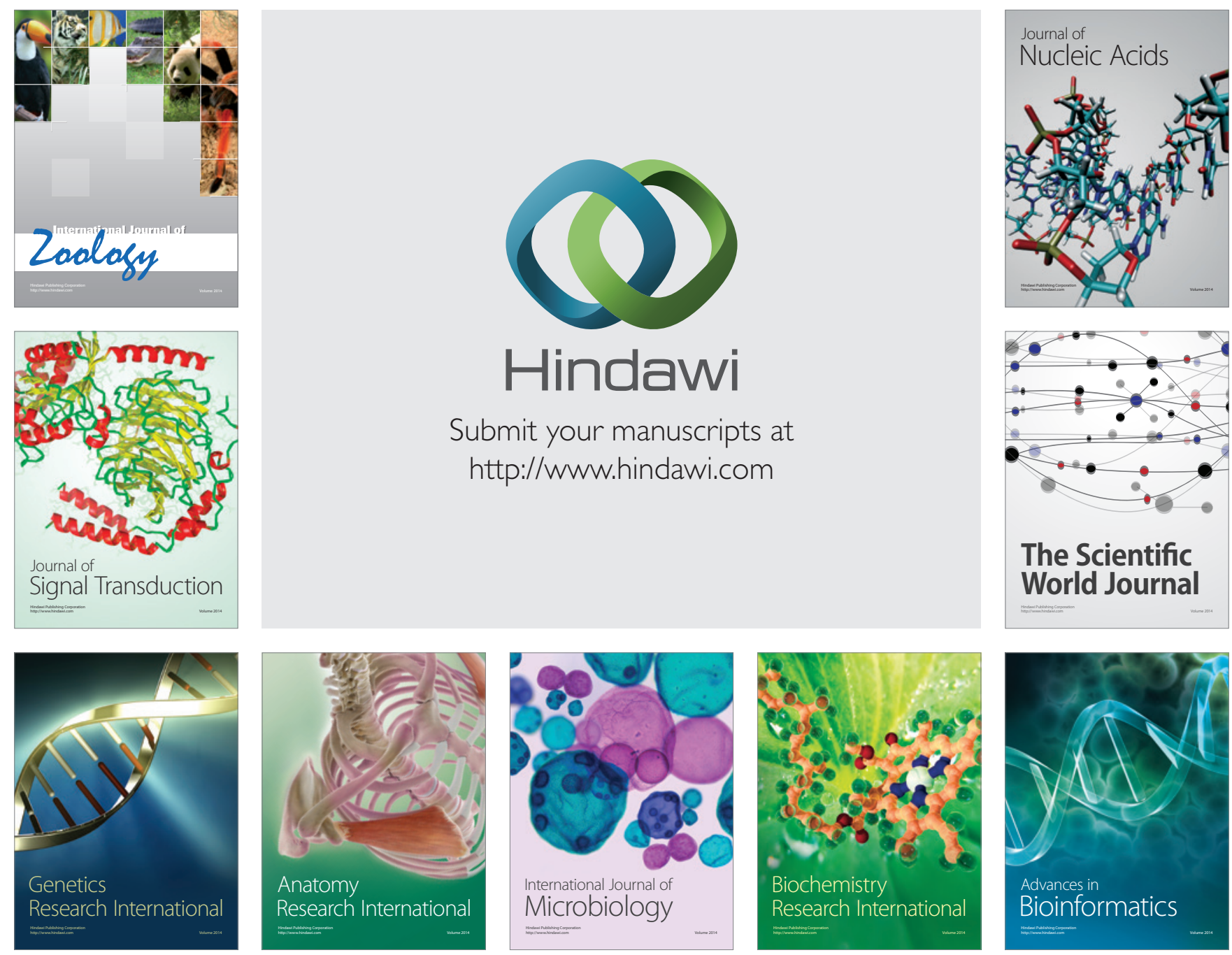

The Scientific World Journal
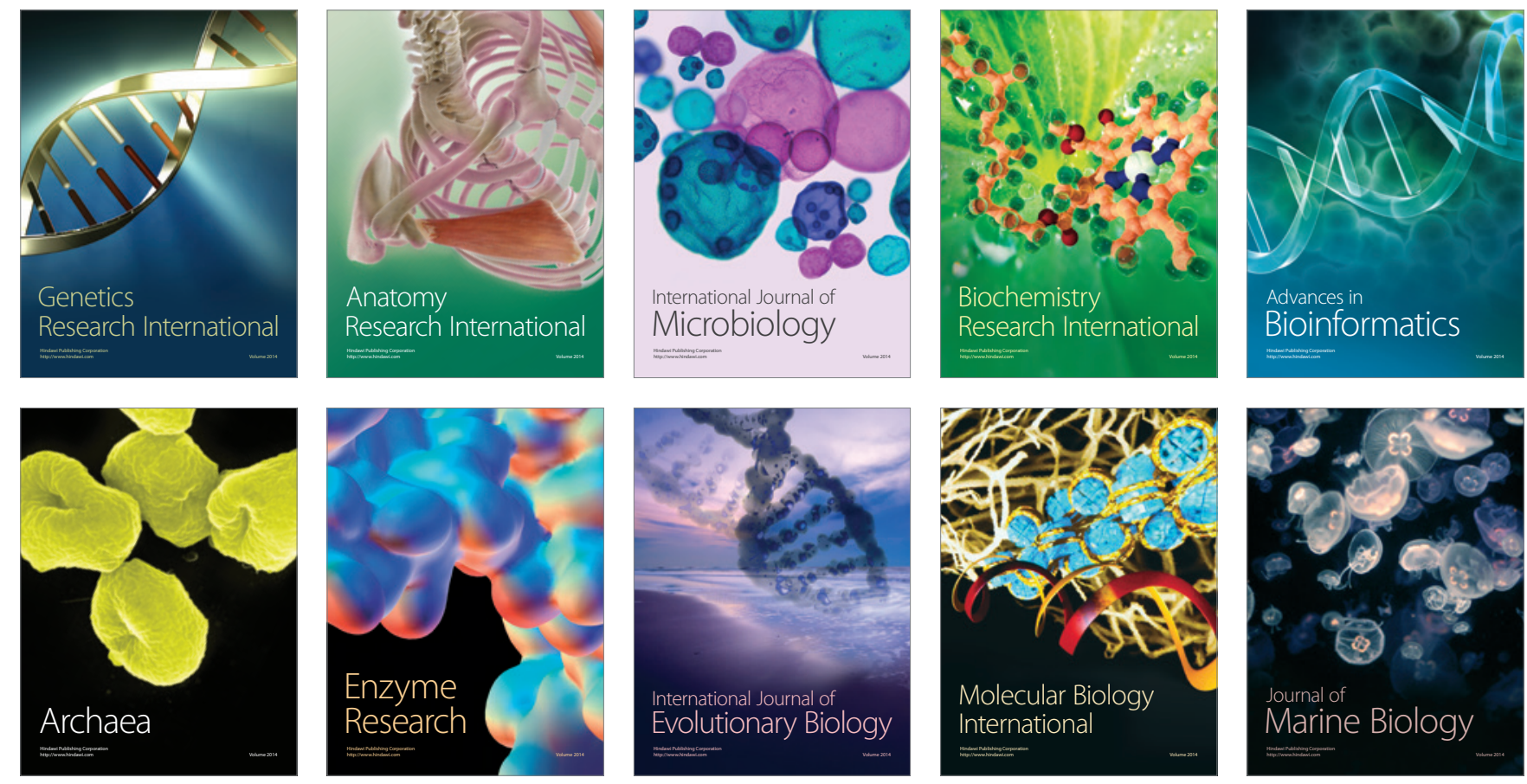